\title{
STWIERDZENIE NIEWAŻNOŚCI UCHWALY PRZEZ RADĘ GMINY
}

\section{I. ŚRODKI NADZORU NAD SAMORZĄDEM TERYTORIALNYM}

Konstytucja RP z 1997 r. ${ }^{1}$, stanowiąc w art. 171 ust. 2: „Organami nadzoru nad działalnością jednostek samorządu terytorialnego są Prezes Rady Ministrów i wojewodowie, a w zakresie spraw finansowych regionalne izby obrachunkowe", rozstrzygnęła wątpliwości co do określenia kręgu organów sprawujących nadzór nad samorządem terytorialnym.

Za kryterium decydujące o zaliczeniu danego organu do kręgu organów nadzorczych uznano wprowadzoną przez ustawę o samorządzie gminnym instytucję „rozstrzygnięcia nadzorczego”. Pojęcie „rozstrzygnięcie nadzorcze” określane było jednak przez naukę w dwojaki sposób. Pierwsze ujęcie sprowadzało się do uznania, iż rozstrzygnięcia nadzorcze wydawane być mogą przez wszelkie organy mające jakiekolwiek uprawnienia nadzorcze nad gmina. Dochodziło tu zatem do wyjścia poza ramy rozdziału 10 ustawy samorządowej2, regulującego kwestie nadzoru nad działalnością komunalna. Druga natomiast koncepcja zakładała, iż działanie ustawodawcy, który w art. 86 wymienił i nazwał konkretne organy „organami nadzoru”, było celowe. A zatem wyłącznie rozstrzygnięcia wydane przez te organy i w formach przewidzianych w rozdziale 10 ustawy uznać można za rozstrzygnięcia nadzorcze ${ }^{3}$.

Sądowa ochrona samodzielności gminy dotyczy działań podejmowanych w stosunku do samorządu terytorialnego przez organy administracji państwowej. Z tego też względu nazywa się te organy wyraźnie organami nadzorczymi. Nie znaczy to jednak, że poza tym uprawnienia nadzorcze nie służą innym organom. A zatem kategoria „rozstrzygnięcia nadzorczego” będzie pomocna przy określaniu zakresu działania sądu administracyjnego w ramach sprawowanej przez niego sądowej ochrony samodzielności gminy. Obecnie przyjmuje się, że organami nadzoru nad działalnością samorządu gminnego, powiatowego i wojewódzkiego są wyłącznie Prezes Rady Ministrów, wojewodowie i regionalne izby obrachunkowe.

$\mathrm{Na}$ zasadzie wyjątku od powyższej reguły uprawnienia nadzorcze o charakterze ustrojowym posiada Sejm. Zgodnie z art. 171 ust. 3 Konstytucji RP:

\footnotetext{
${ }^{1}$ Dz. U. 1997, Nr 78, poz. 483.

${ }^{2}$ Ustawa z 8 marca 1990 r. o samorządzie gminnym, t.jedn.: Dz. U. 2013, poz. 594 (dalej jako u.s.g.).

${ }^{3}$ Por. B. Dolnicki, Samorzqd terytorialny, wyd. 5, Wolters Kluwer, Warszawa 2012, s. 396-397.
} 
„Sejm, na wniosek Prezesa Rady Ministrów, może rozwiązać organ stanowiący samorządu terytorialnego, jeżeli organ ten rażąco narusza Konstytucję lub ustawy". Analogiczne rozwiązania zawierają ustawy samorządowe (art. 83 ust. 1 u.s.p. i art. 84 ust. 1 u.s.w. mają brzmienie takie jak art. 96 ust. 1 u.s.g.) $)^{4}$. $\mathrm{Na}$ uchwałę Sejmu w sprawie rozwiązania organu stanowiącego jednostki samorządu terytorialnego nie przysługuje skarga do sądu administracyjnego.

Bez wątpienia sądu administracyjnego nie można uznać za organ nadzorczy nad samorzadem terytorialnym. Rozpoznawanie skarg na uchwały, działania lub zaniechania organów samorządowych należy do sfery wymiaru sprawiedliwości. Działalność sądów administracyjnych zaliczyć należy do sądowej kontroli administracji publicznej. Natomiast podkreślenia wymaga stale rosnąca rola sądu administracyjnego w całym procesie sprawowania nadzoru państwowego nad samorządem terytorialnym.

Oprócz organów nadzoru wymienionych w Konstytucji oraz ustawach samorządowych pojawić się mogą organy, które niejako ubocznie posiadać będa kompetencje nadzorcze w stosunku do samorządu. Należałoby je wówczas uznać za „organy nadzoru w znaczeniu funkcjonalnym”.

Uchwała lub zarządzenie organu gminy, powiatu lub województwa sprzeczne z prawem sa nieważne. O nieważności orzeka właściwy organ nadzoru w terminie nie dłuższym niż 30 dni od dnia doręczenia uchwały (zarządzenia). Stwierdzenie nieważności uchwały (zarządzenia) organu samorządu terytorialnego zostało uznane przez ustawodawcę za podstawowy środek nadzoru. W odniesieniu do tego środka zostały rozbudowane w ustawach samorządowych reguły postępowania. Ponadto w ustawach o samorządzie gminnym i powiatowym znajduje się odesłanie do odpowiedniego stosowania przepisów Kodeksu postępowania administracyjnego ${ }^{5}$, a w ustawie o samorządzie województwa - do przepisów o kontroli sądowej decyzji administracyjnych. Zabieg ten jednak odniósł skutek wręcz odwrotny od zamierzonego - zamiast uprościć postępowanie w sprawie stwierdzenia nieważności znacznie go skomplikował. Pojawiło się bowiem wiele pytań i kolizji na zbiegu obu reżimów ustawowych.

Jeżeli organ nadzoru w terminie 30 dni od doręczenia mu uchwały (zarzadzenia) nie stwierdził we własnym zakresie jej nieważności, może tego dokonać jedynie sąd administracyjny na skutek skargi wniesionej przez ten organ.

Okazuje się jednak, że ustawodawca nie przewidział wszelkich możliwych sytuacji. Przedmiotem niniejszego opracowania jest wykazanie, że w szczególnej sytuacji rada gminy powinna być zaliczona do „organów nadzoru w znaczeniu funkcjonalnym", może bowiem na podstawie art. $54 \S 3$ p.p.s.a. ${ }^{6}$ stwierdzić nieważność własnej uchwały w przedmiocie miejscowego planu zagospodarowania przestrzennego. W celu nakreślenia problemu niezbędne jest przedstawienie stanu faktycznego.

${ }^{4}$ Ustawa z 5 czerwca 1998 r. o samorządzie powiatowym, t.jedn.: Dz. U. 2013, poz. 595 (dalej jako u.s.p.); ustawa z 5 czerwca 1998 r. o samorządzie województwa, t.jedn.: Dz. U. 2013, poz. 596 (dalej jako u.s.w.).

${ }_{5}^{5}$ Ustawa z 14 czerwca 1960 r. - Kodeks postępowania administracyjnego, t.jedn.: Dz. U. 2013, poz. 267 (dalej jako: k.p.a.).

${ }^{6}$ Ustawa z 30 sierpnia 2002 r. - Prawo o postępowaniu przed sądami administracyjnymi, Dz. U. 2002, Nr 153, poz. 1270 ze zm. (dalej jako p.p.s.a). 


\section{STAN FAKTYCZNY}

Rada Miasta uchwałą z kwietnia 2004 r. ustanowiła miejscowy plan zagospodarowania przestrzennego centrum miasta - obszar „C”. Z uwagi na upływ terminu do wydania rozstrzygnięcia nadzorczego, zgodnie $\mathrm{z}$ art. 91 ust. 1 u.s.g. wojewoda 12 listopada 2013 r. wniósł skargę do wojewódzkiego sądu administracyjnego z żądaniem stwierdzenia nieważności tej uchwały

W skardze wojewoda wniósł o stwierdzenie nieważności uchwały jako niezgodnej z art. 10 ust. 1 i 3 ustawy z 7 lipca 1994 r. o zagospodarowaniu przestrzennym $^{7}$ oraz art. 64 ust. 3 i 94 ust. 3 Konstytucji Rzeczypospolitej Polskiej. Zdaniem wojewody zaskarżona uchwała zawiera liczne ustalenia dotyczące przeznaczenia terenów, których treść i znaczenie są niejednoznaczne, dopuszczające odstapienie od ustalonego przeznaczenia, bądź jego zmianę uwarunkowaną koniecznością uzyskania opinii lub uzgodnienia - co stoi $\mathrm{w}$ sprzeczności z zasadami obowiąującymi w procesie sporządzania planu miejscowego.

Rada Miasta, uznając skargę za zasadną w całości, na podstawie art. 54 $\S 3$ p.p.s.a. podjęła uchwałę 16 grudnia $2013 \mathrm{r}$. w sprawie stwierdzenia nieważności zaskarżonej przez wojewodę uchwały Rady Miasta z 27 kwietnia 2004 r. w sprawie miejscowego planu zagospodarowania przestrzennego.

Wojewoda wydał następnie rozstrzygnięcie nadzorcze z 10 stycznia 2014 r., którym stwierdził nieważność uchwały Rady Miasta z 16 grudnia 2013 r.

$\mathrm{Na}$ ww. rozstrzygnięcie nadzorcze miasto wniosło skargę do Wojewódzkiego Sądu Administracyjnego, który po rozpatrzeniu skargi z 31 stycznia 2014 r., wyrokiem z 8 maja 2014 r. (II SA/Gl 348/14) oddalił skargę, utrzymując w mocy akt nadzoru wojewody.

W uzasadnieniu zaskarżonego wyroku Sąd przyznał, że art. 54 § 3 p.p.s.a. może stanowić podstawę wydania uchwały w trybie autokontroli, jednak znajdujący się w nim zwrot „w zakresie swojej właściwości” stanowi istotne ograniczenie tej instytucji. Następnie stwierdził, że w przedmiotowej sprawie ograniczenie takie wynika z art. 91 ust. 1 oraz art. 93 ust. 1 u.s.g. Zdaniem Sądu orzekającego: ,jedynie organ nadzoru oraz sąd administracyjny maja kompetencje $\mathrm{w}$ zakresie stwierdzenia nieważności uchwał rady gminy, natomiast kompetencji takiej nie posiada rada gminy".

W stosunku do tego wyroku miasto wniosło skargę kasacyjną do NSA, podnosząc zarzut naruszenia prawa materialnego. Zaskarżony wyrok został wydany niezgodnie $\mathrm{z}$ prawem ze względu na naruszenie przepisu art. 54 $\S 3$ p.p.s.a. w zw. art. 18 ustawy z 8 marca 1990 r. o samorządzie gminnym.

Zgodnie z treścia art. $54 \S 3$ p.p.s.a.: „Organ, którego działanie lub bezczynność zaskarżono, może w zakresie swojej właściwości uwzględnić skargę w całości do dnia rozpoczęcia rozprawy".

Rada Miasta uwzględniła skargę w całości. Wydała rozstrzygnięcie zgodne z żądaniem zawartym w skardze wojewody. Zatem uchwała z 16 grudnia

\footnotetext{
${ }^{7}$ Dz. U. 1994, Nr 89, poz. 415 ze zm.
} 
2013 r. w pełni realizowała interes skarżącego ${ }^{8}$. Wojewódzki Sąd Administracyjny uznał jednak, że zastosowanie trybu samokontroli przez Radę Miasta było niedopuszczalne. Wskazał, że przepis art. $54 \S 3$ p.p.s.a., który przyznaje radzie gminy prawo do stwierdzenia nieważności wydanego przez nią aktu prawa miejscowego, zaskarżonego do wojewódzkiego sądu administracyjnego, ograniczone jest przepisami art. 91 i art. 93 u.s.g., które - zdaniem Sądu uszczuplają kompetencje rady gminy.

\section{WYROK NACZELNEGO SADU ADMINISTRACYJNEGO Z 18 LISTOPADA 2014 R. (II OSK 2377/14)}

Naczelny Sąd Administracyjny - przyjmując, że spór prawny w tej sprawie dotyczy tego, czy rada gminy może na podstawie art. $54 \S 3$ p.p.s.a. stwierdzić nieważność własnej uchwały w przedmiocie miejscowego planu zagospodarowania przestrzennego, wydał precedensowe orzeczenie.

Zgodnie z powołanym przepisem organ, którego działanie, bezczynność lub przewlekłe prowadzenie postępowania zaskarżono, może w zakresie swojej właściwości uwzględnić skargę w całości do dnia rozpoczęcia rozprawy. Uwzględniając skargę, organ stwierdza jednocześnie, czy działanie, bezczynność lub przewlekłe prowadzenie postępowania miały miejsce bez podstawy prawnej albo z rażącym naruszeniem prawa. Celem wprowadzenia tego przepisu było umożliwienie organowi administracji weryfikacji własnego działania lub bezczynności bez konieczności angażowania sądu administracyjnego w ocenę jego zgodności z prawem. Przepis ten służy więc realizacji zasady szybkości postępowania wyrażonej w art. 7 p.p.s.a. i powinien być wykładany w sposób zapewniający najpełniejszą realizację tej zasady ogólnej postępowania sądowoadministracyjnego.

W doktrynie prawa administracyjnego przeważa pogląd, że przepis art. $54 \S 3$ p.p.s.a. stanowi nowe, samodzielne upoważnienie organu administracji publicznej do weryfikacji własnej decyzji, wiążące się wyłącznie z zaskarżeniem tej decyzji do sądu administracyjnego (Z. Kmieciak [w:] System Prawa Administracyjnego, Tom 10, Sądowa kontrola administracji publicznej, red. R. Hauser, Z. Niewiadomski, A. Wróbel, Warszawa 2014, s. 305 i powołana tam literatura).

Podobny pogląd wyrażany był też w orzecznictwie Naczelnego Sądu Administracyjnego i Sądu Najwyższego na gruncie poprzednio obowiązujących w tym zakresie przepisów art. 38 ust. 2 ustawy z dnia 11 maja 1995 r. o Naczelnym Sądzie Administracyjnym (Dz.U. nr 74 poz. 368 ze zm.) i art. $200 \S 2$ k.p.a.

W uchwale pełnego składu Izby Cywilnej i Administracyjnej z dnia 15 grudnia $1984 \mathrm{r}$., III AZP 8/83 (OSNCP 1985, nr 10, poz. 143) Sąd Najwyższy, w odniesieniu do art. 200 $\S 2$ k.p.a., stwierdził, że autokontrola zaskarżonej decyzji przez organ, który ją wydał, stanowi nowe, samodzielne upoważnienie organu administracji publicznej do weryfikacji własnej decyzji, wiążące się wyłącznie z zaskarżeniem decyzji do sądu administracyjnego. W uchwale składu siedmiu sędziów Naczelnego Sądu Administracyjnego z dnia 5 lipca 1999 r., FPS 20/98 (ONSA 1999, nr 4, poz. 120) przyjęto, iż na podstawie art. 38 ust. 2 ustawy z dnia 11 maja 1995 r. o Naczelnym Sązie Administracyjnym (Dz.U. nr 74 poz. 368 ze zm.) Izba Skarbowa, na której decyzję odwoławczą wniesiono skargę do Naczelnego Sądu Administracyjnego uprawniona jest do stwierdzenia nieważności zaskarżonej decyzji i poprzedzającej ją decyzji organu podatkowego. [...]

${ }^{8}$ Por. uchwałę składu 7 sędziów NSA z 5 lipca 1999 r., FPS 20/98, Lex Polonica, nr 340233, ONSA 1999, nr 4, poz. 120. 
W wyroku z dnia 18 listopada 2011 r., I OSK 630/11 (publ. Centralna Baza Orzeczeń Sadów Administracyjnych, www.nsa.gov.pl), Naczelny Sąd Administracyjny wskazał, że art. 38 ust. 2 ustawy o NSA nie określał szczegółowo przesłanek do skorzystania z moźliwości $\mathrm{w}$ nim zawartych ani też prawnych form, w jakich miało nastapić przewidziane $\mathrm{w}$ tym przepisie „uwzględnienie skargi w całości”. W orzeczeniach Naczelnego Sądu Administracyjnego, gdy chodzi o wykładnię tego przepisu, wyrażane były także poglądy, że art. 38 ust. 2 ustawy o NSA upoważnia organ administracji publicznej do uwzględnienia skargi w całości, a zatem do wydania rozstrzygnięcia jakie w rozumieniu ustawy o Naczelnym Sądzie Administracyjnym stanowi uwzględnienie tego środka prawnego. Chodzi tutaj o rodzaje rozstrzygnięć, które zostały wymienione w art. 22 ust. 1 pkt 1-3 ustawy o NSA. Oznacza to, że organ może w oparciu o art. 38 ust. 2 ustawy o NSA uchylić decyzję lub postanowienie w całości albo w części, stwierdzić ich nieważność lub niezgodność z prawem. Rodzaj rozstrzygnięcia zależeć zaś będzie w konkretnej sprawie od przedmiotu zaskarżenia i sformułowanego w skardze żądania strony (patrz np. wyrok NSA z 27 czerwca 2003 r., I SA 215/02, LEX nr 149489, wyrok NSA z 17 kwietnia 2000 r., I SA/Ka 2271/99, LEX nr 423970, wyrok NSA z 21 marca 2002 r., III SA 2807/00, LEX nr 54305).

Treść art. 54 § 3 p.p.s.a. jest w istocie tożsama z treścią art. 38 ust. 2 ustawy o Naczelnym Sadzie Administracyjnym, w związku z czym poglądy wyrażone w powołanych wyżej uchwałach i wyrokach Naczelnego Sądu Administracyjnego zachowują swoją aktualność, mimo zmiany stanu prawnego.

Przedstawione argumenty przemawiają za przyjęciem, iż przepis art. $54 \S 3$ p.p.s.a., pomimo tego, iż zawarty jest w ustawie procesowej, jest przepisem o charakterze kompetencyjnym, dającym organowi szczególne uprawnienie w ramach toczącego się postępowania sądowoadministracyjnego do podjęcia rozstrzygnięcia uwzględniającego skargę zgodnie z jej żądaniem przy zastosowaniu rodzajów rozstrzygnięć podejmowanych przed sąd administracyjny w razie uwzględnienia skargi (art. 145-150 p.p.s.a.). Przesłankami zastosowania tego przepisu przez organ są: uwzględnienie skargi w całości oraz zachowanie terminu (do dnia rozpoczęcia rozprawy). Uprawnienie organu do działania w ramach autokontroli w zakresie wyboru form i rodzaju rozstrzygnięcia sprawy jest powiązane z treścią żądania skargi oraz z przedmiotem zaskarżenia.

Przepis art. $54 \S 3$ p.p.s.a. ma charakter ogólny, nie zawiera żadnych wyłączeń przedmiotowych lub podmiotowych. Przyjąć więc należy, że przepis ten odnosi się do wszystkich działań lub bezczynności, o których mowa w art. $3 \S 2$ i 3 p.p.s.a., a zatem również do zaskarżonych uchwał rady gminy stanowiących akty prawa miejscowego (art. $3 \S 2$ pkt 5 p.p.s.a.). Jedynym ograniczeniem zastosowania przez organ art. $54 \S 3$ p.p.s.a. jest to, aby organ, uwzględniajac skargę, działał „w zakresie swojej właściwości”. Właściwość organu to zdolność prawna do rozstrzygania określonego rodzaju spraw. W ocenie Naczelnego Sądu Administracyjnego pojęcie „właściwości” w rozumieniu art. $54 \S 3$ p.p.s.a. powinno być rozumiane podobnie jak na gruncie przepisów Kodeksu postępowania administracyjnego. W przypadku art. 54 § 3 p.p.s.a. chodzi więc o zachowanie właściwości rzeczowej i miejscowej organu. Właściwość rzeczowa organu administracji publicznej ustala się według przepisów o zakresie jego działania (art. 20 k.p.a.). Właściwość rzeczową trzeba ustalać na podstawie przepisów ustaw materialnoprawnych oraz tych przepisów ustaw ustrojowych, które dotyczą kompetencji organów administracji publicznej (B. Adamiak [w:] B. Adamiak, J. Borkowski, Kodeks postępowania administracyjnego. Komentarz, Warszawa, 2011, s. 108). Przy czym podkreślenia wymaga, że do zakresu pojęcia właściwości rzeczowej organu nie należy forma ani rodzaj podjętego rozstrzygnięcia. (NSA powołał się przy tym na postanowienie z dnia 29 grudnia 2009 r., II OW 73/09).

$\mathrm{W}$ tej sprawie nie ulega wątpliwości, że rada gminy posiada kompetencje do podejmowania uchwał w sprawie miejscowych planów zagospodarowania przestrzennego. Stanowi o tym art. 18 ust. 2 pkt 5 ustawy o samorządzie gminnym. W myśl tego przepisu do wyłącznej właściwości rady gminy należy uchwalanie miejscowych planów zagospodarowania przestrzennego. Takie same kompetencje dla rady gminy przewiduja przepisy art. 20 ust. 1, art. 27 ustawy z dnia 27 marca 2003 r. o planowaniu i zagospodarowaniu przestrzennym (Dz. U. z 2012 r., poz. 647 ze zm.). Skoro zatem rada gminy jest właściwa, a więc posiada zdolność prawną do władczego rozstrzygania w przedmiocie miejscowego planu zagospodarowania przestrzenne- 
go (jego uchwalenia, zmiany, uchylenia), to „w zakresie swojej właściwości” może również uwzględnić skargę na uchwałę $\mathrm{w}$ przedmiocie miejscowego planu zagospodarowania przestrzennego, stwierdzając jej nieważność na podstawie art. $54 \S 3$ p.p.s.a.

Rację ma strona skarżąca, iż Sąd I instancji błędnie przyjął, że przepisy art. 91 ust. 1 i art. 93 ust. 1 ustawy o samorządzie gminnym pozbawiają radę gminy prawa do zastosowania trybu „samokontroli” poprzez stwierdzenie nieważności wydanego przez nią aktu prawa miejscowego zaskarżonego do wojewódzkiego sądu administracyjnego. Zgodnie z art. 91 ust. 1 ustawy o samorządzie gminnym uchwała lub zarządzenie organu gminy sprzeczne z prawem są nieważne. O nieważności uchwały lub zarządzenia w całości lub w części orzeka organ nadzoru w terminie nie dłuższym niż 30 dni od dnia doręczenia uchwały lub zarządzenia, w trybie określonym w art. 90. Natomiast przepis art. 93 ust. 1 tej ustawy stanowi, że po upływie terminu wskazanego w art. 91 ust. 1 organ nadzoru nie może we własnym zakresie stwierdzić nieważności uchwały lub zarządzenia organu gminy. W tym przypadku organ nadzoru może zaskarżyć uchwałę lub zarządzenie do sądu administracyjnego. Powołane przepisy reguluja jedynie tryb postępowania nadzorczego i maja zastosowanie do momentu wniesienia skargi do sądu administracyjnego. Po wniesieniu skargi zastosowanie maja przepisy ustawy - Prawo o postępowaniu przed sądami administracyjnymi, a zatem również art. $54 \S 3$ p.p.s.a. To, że przepisy ustawy o samorządzie gminnym przyznają uprawnienie do stwierdzenia nieważności uchwały rady gminy wyłącznie organowi nadzoru, nie wyklucza możliwości stosowania art. 54 $\S 3$ p.p.s.a. Czym innym jest bowiem postępowanie nadzorcze prowadzone przez organ nadzoru na podstawie art. 85-92 ustawy o samorządzie gminnym, a czym innym postępowanie sądowoadministracyjne wywołane skargą organu nadzoru.

Przedstawiona argumentacja przemawia za przyjęciem stanowiska, iż rada gminy, działając na podstawie art. $54 \S 3$ p.p.s.a. w zw. z art. $147 \S 1$ p.p.s.a., może uwzględnić skargę do sądu administracyjnego na własną uchwałę w przedmiocie miejscowego planu zagospodarowania przestrzennego i stwierdzić jej nieważność. Pogląd przeciwny prowadziłby do wyłączenia możliwości zastosowania art. $54 \S 3$ p.p.s.a. w przypadkach, gdy przedmiotem skargi jest uchwała rady gminy (analogicznie również rady powiatu, sejmiku województwa) będąca aktem prawa miejscowego, czy też inne uchwały lub akty, których mowa w art. $3 \S 2$ pkt 5 i 6 p.p.s.a. Tak szerokiego wyłączenia zastosowania art. $54 \S 3$ p.p.s.a. nie można wyprowadzać w drodze wykładni, lecz wymagałoby to wyraźnej regulacji ustawowej.

\section{W pełni podzielam stanowisko NSA, że:}

[...] uchwała rady gminy wydana $\mathrm{w}$ trybie autokontroli podlega kontroli sądu na zasadach ogólnych (por. uchwała siedmiu sędziów NSA z dnia 20 marca 2000 r., OPS 16/99, publ. ONSA 2000 , Nr 3, poz. 94). Skarga na taką uchwałę przysługuje więc zarówno organowi nadzoru na podstawie art. 93 ust. 1 ustawy o samorządzie gminnym, jak i innym podmiotom na podstawie art. 101 ust. 1 ustawy o samorządzie gminnym. Taka uchwała nie może więc zostać podjęta przez radę gminy w sposób dowolny, lecz wymagane jest w tym zakresie spełnienie szeregu warunków formalnych (wniesienie skargi na uchwałę rady gminy, uwzględnienie żądania skargi w całości, zachowanie terminu), jak i materialnoprawnych (niezgodność z prawem zaskarżonej uchwały skutkująca uwzględnieniem skargi), których spełnienie podlega kontroli sądu.

\section{W omawianym orzeczeniu zawarta została kolejna bardzo istotna dla prak- tyki teza, zgodnie z którą:}

[...] uchwała rady gminy stwierdzająca nieważność uchwały w przedmiocie miejscowego planu zagospodarowania przestrzennego wydana na podstawie art. $54 \S 3$ p.p.s.a. podlega ogłoszeniu w dzienniku urzędowym województwa na podstawie art. 13 pkt 2 ustawy z dnia 20 lipca 2000 r. o ogłaszaniu aktów normatywnych i niektórych innych aktów (Dz.U. z 2011 r., Nr 197, poz. 1172 ze zm.). Tego rodzaju uchwała jest bowiem aktem normatywnym, eliminującym $\mathrm{z}$ obrotu prawnego akt prawa miejscowego jakim jest uchwała w przedmiocie miejscowego planu zagospodarowania przestrzennego, zatem ma cechy aktu prawa miejscowego. 


\section{W omawianej sprawie złożone zostało zdanie odrębne:}

Zgadzając się z okolicznościa, iż przepis art. 54 § 3 P.p.s.a. nie określa form funkcjonowania administracji publicznej, których zaskarżenie uprawnia organ administracji do działania w trybie autokontroli, przyjęto, że relatywnie odnosi się do wszystkich działań lub bezczynności, o których mowa w art. 3 § 2 i 3 P.p.s.a., a zatem również do zaskarżonych uchwał rady gminy stanowiących akty prawa miejscowego (art. $3 \S 2$ pkt 5 P.p.s.a.). Nie dotyczy on wszystkich przypadków objętych kognicją sądu administracyjnego, lecz tylko tych, które zostały zainicjowane wskutek wniesienia skargi, a przedmiotem oceny legalności sądu jest „działanie” lub „bezczynność”. Organ, którego działanie lub bezczynność zaskarżono, może uwzględnić skargę w całości do dnia rozpoczęcia rozprawy. Uwzględnienie skargi oznacza uwzględnienie zarzutów i wniosków skargi oraz powołanej w niej podstawy prawnej.

Przepis o autokontroli zawarty jest w ustępie 3 jednostki redakcyjnej art. 54 p.p.s.a., określającej tryb wnoszenia skarg do sądu administracyjnego. Stosownie do art. $54 \S 1$ p.p.s.a., skargę do sądu administracyjnego wnosi się za pośrednictwem organu, którego działanie, bezczynność lub przewlekłe prowadzenie postępowania jest przedmiotem skargi. Natomiast organ ten przekazuje skargę sądowi wraz z aktami sprawy i odpowiedzią na skargę, w terminie trzydziestu dni od dnia jej wniesienia (art. $54 \S 2$ p.p.s.a.). Ustawa przewiduje więc pośredni tryb wnoszenia skargi do sądu administracyjnego. Organ, którego działanie, bezczynność lub przewlekłe prowadzenie postępowania jest przedmiotem zaskarżenia, ma trzydzieści dni na udzielenie odpowiedzi na skargę oraz przesłanie jej sądowi wraz z aktami.

Dokonując analizy normatywnej postanowień ustępu $3 \mathrm{w}$ kontekście całej jednostki redakcyjnej art. 54 P.p.s.a., należy dojść do przekonania, że instytucja autokontroli odnosi się do spraw administracyjnych załatwianych w drodze decyzji, postanowienia, bądź innych aktów lub czynności z zakresu administracji publicznej, bezczynności lub przewlekłości wnoszonych do sądu za pośrednictwem organu, którego działanie, bezczynność lub przewlekłe prowadzenie postępowania jest przedmiotem skargi.

Relewantną przesłanka, ograniczającą możliwość skorzystania z uprawnienia do autokontroli, jest posiadanie przez organ, w czasie korzystania z tej instytucji, kompetencji do załatwiania danego rodzaju spraw administracyjnych. Ustawodawca związał bowiem organ, dopuszczając uwzględnienie skargi w całości, tylko: „w zakresie swojej właściwości”, co oznacza, że może uwzględnić skargę, tylko jeśli na podstawie przepisów prawa jest właściwy do weryfikacji własnego rozstrzygnięcia

Ustawodawca, formułując uprawnienie do autokontroli, wyraźnie wskazał, że organ może je wykorzystać jedynie w zakresie swojej właściwości i kompetencji, co niewątpliwie implikuje zarówno formę, jak i tryb działań autokontrolnych. Zawarty w art. 54 § 3 P.p.s.a. zwrot normatywny: „może uwzględnić skargę w całości” oznacza, że organ stosuje obowiązujące go zasady procedury właściwej dla danej prawnej formy „załatwienia sprawy”. Zawsze bowiem forma działania autokontrolnego organu administracji publicznej będzie tożsama z formą działania, do którego ma się odnosić.

Konieczność działania w ramach właściwości oznacza, że instytucja autokontroli nie stanowi nowego, samodzielnego upoważnienia organu administracji publicznej do weryfikacji własnego rozstrzygnięcia. Norma art. 54 § 3 P.p.s.a. nie może być potraktowana, jako samodzielna podstawa wzruszenia przez organ administracji publicznej zaskarżonego aktu lub czynności, ponieważ jest to przepis procesowy umieszczony w rozdziale 2 P.p.s.a., regulującym zasady i tryb wnoszenia skargi do sądu administracyjnego, a więc nie ustanawia on zadań i kompetencji organu administracji publicznej (por. J. Borkowski, Glosa do wyroku NSA z dnia 24 lutego 1995 r., III SA 19/94, OSP 1997, z. 6, s. 294; K. Sobieralski, Uprawnienia samokontrolne, op. cit., s. 60-61). Przepisy procesowe nie mogą bowiem stanowić podstawy dla ustanawiania 
norm kompetencyjnych, ponieważ to normy materialnoprawne i ustrojowe stanowią źródło kompetencji organu do wydania prawnie przewidzianego rozstrzygnięcia (por. B. Adamiak [w:] B. Adamiak, J. Borkowski, Kodeks postępowania administracyjnego. Komentarz, Warszawa, 2011, s.108).

\section{Uzasadnienie zdania odrębnego wykazuje jednak niekonsekwencje:}

Zgadzając się z okolicznościa, iż przepis art. 54 § 3 P.p.s.a. nie określa form funkcjonowania administracji publicznej, których zaskarżenie uprawnia organ administracji do działania w trybie autokontroli, przyjęto, że relatywnie odnosi się do wszystkich działań lub bezczynności, o których mowa w art. 3 § 2 i 3 P.p.s.a., a zatem również do zaskarżonych uchwał rady gminy stanowiących akty prawa miejscowego (art. $3 \S 2$ pkt 5 P.p.s.a.). Nie dotyczy on wszystkich przypadków objętych kognicją sądu administracyjnego, lecz tylko tych, które zostały zainicjowane wskutek wniesienia skargi, a przedmiotem oceny legalności sądu jest „działanie” lub „bezczynność”. Organ, którego działanie lub bezczynność zaskarżono, może uwzględnić skargę w całości do dnia rozpoczęcia rozprawy. Uwzględnienie skargi oznacza uwzględnienie zarzutów i wniosków skargi oraz powołanej w niej podstawy prawnej.

Prezentowane stanowisko, moim zdaniem, przeczy idei instytucji autokontroli oraz realizowanej przez nią zasadzie ekonomii procesowej. Dalej w uzasadnieniu zdania odrębnego znajdujemy stwierdzenie, jakoby:

NSA wykreował z instytucji procesowej art. 54 § 3 P.p.s.a., normę kompetencyjną dająca organowi stanowiącemu samorządu gminnego, prawo do podejmowania uchwał stwierdzających nieważność własnych uchwał, czyli dokonywania „autonadzoru”, co jest nie do zaakceptowania z ustrojowego punktu widzenia, biorąc pod uwagę normatywne przesłanki determinujące cel $\mathrm{i}$ istotę instytucji nadzoru nad działalnością samorządu gminnego.

Stanowisko to nie zasługuje na akceptację.

Nieuprawnione wydaje się również powoływanie na konstytucyjne zasady demokratycznego państwa prawa (art. 2 Konstytucji RP) oraz legalizmu (art. 7 Konstytucji RP) i dokonywanie zbyt daleko idącej ich interpretacji:

Zasada, według której wszystkie organy władzy i administracji państwowej działają na podstawie przepisów prawa, zawsze oznacza konieczność istnienia wyraźnej podstawy prawnej dla jakiejkolwiek działalności organu państwa. Organy władzy publicznej mogą działać tylko wtedy, gdy jest do tego podstawa prawna i tylko w tych wypadkach, gdy prawo im na to zezwala. Natomiast na podstawie postanowień art. 54 § 3 P.p.s.a., nie można kreować norm kompetencji prawodawczej.

Opowiadając się za słusznością omawianego wyroku Naczelnego Sądu Administracyjnego z 18 listopada 2014 r. (II OSK 2377/14), należy podnieść kilka argumentów, które przedstawiono poniżej.

\section{SAMODZIELNOŚĆ PODSTAWY PRAWNEJ AUTOKONTROLI}

Artykuł $54 \S 3$ p.p.s.a. stanowi samoistną podstawę prawną do dokonania autokontroli przez organ administracji. Jedyny warunek, jaki musi być spełniony, to uwzględnienie skargi w całości. Podkreśla się przy tym w literaturze, 
że uwzględnienie skargi w całości oznacza uznanie za uzasadnione zarówno zarzutów oraz wniosków skargi, jak i wskazanej w niej podstawy prawnej ${ }^{9}$.

Zgodnie z wyrokiem Wojewódzkiego Sądu Administracyjnego w Szczecinie z 9 lutego 2011 r. (II SA/Sz 1100/2010, Lex Polonica, nr 2589825): „Artykuł 54 $\S 3$ Prawa o postępowaniu przed sądami administracyjnymi stanowi samodzielną podstawę postępowania prowadzonego w ramach autokontroli”.

Pogląd taki wyraził również Jan P. Tarno, wskazując, że regulacja zawarta w art. $54 \S 3$ p.p.s.a. „stanowi samoistną podstawę prawną do dokonania autokontroli przez organ administracji"10.

W podobnym tonie wypowiedział się Ryszard Mikosz, uznajacc, że regulacje dotyczące autokontroli stanowią dla organu administracji, który wydał zaskarżoną decyzję, samoistne upoważnienie do jej weryfikacji ${ }^{11}$.

W orzecznictwie również dominuje pogląd, w myśl którego art. 54 § 3 p.p.s.a. stanowi samoistną podstawę do weryfikacji decyzji w trybie samokontroli przez organ administracji, który wydał zaskarżoną do sądu decyzję. Pogląd taki wyraził przykładowo Naczelny Sąd Administracyjny, stwierdzajac: „Przepis art. 54 § 3 ustawy z dnia 30 sierpnia 2002 r. - Prawo o postępowaniu przed sądami administracyjnymi (Dz.U. Nr 153, poz. 1270 ze zm.) jako przepis szczególny stanowi samoistną podstawę wydania decyzji administracyjnej. Jest to jeden z przypadków, o których mowa w art. 163 k.p.a." (wyrok NSA z 4 marca 2008 r., II OSK 123/07).

Pogląd, według którego art. $54 \S 3$ p.p.s.a. stanowi samoistną podstawę do weryfikacji decyzji w trybie samokontroli, wyraził także Wojewódzki Sąd Administracyjny w Warszawie, wskazując: „W doktrynie prawa i postępowania administracyjnego oraz w orzecznictwie sądowoadministracyjnym wskazuje się, iż art. $54 \S 3 \mathrm{ww}$. ustawy stanowi samoistną podstawę prawną do dokonania autokontroli przez organ administracji publicznej. Jedynym warunkiem, jaki musi zostać spełniony, aby organ mógł zastosować tę instytucję, jest uwzględnienie przez ten organ w całości skargi do sądu administracyjnego [...]" (wyrok WSA w Warszawie z 4 maja 2009 r., IV SA/Wa 23/09).

\section{ISTOTA AUTOKONTROLI}

Skoro wyjaśniany przepis stanowi samodzielną podstawę postępowania prowadzonego w ramach autokontroli, to - rozważając możliwość uwzględnienia skargi - organ administracyjny powinien dokonywać oceny jej zasadności wedle tych samych kryteriów, co sąd administracyjny ${ }^{12}$.

9 A. Kabat, Skarga do sqdu administracyjnego na decyzje Komisji Nadzoru Bankowego (zagadnienia wybrane), „Prawo Bankowe” 2004, nr 12, s. 33 i n.

${ }^{10}$ J. P. Tarno et al., Sadowa kontrola administracji. Podręcznik akademicki, Warszawa 2006, s. 130

11 R. Mikosz, Skutki prawne uwzględnienia przez organ administracji publicznej skargi wniesionej do sqdu administracyjnego, „Zeszyty Naukowe Sądownictwa Administracyjnego” 2007, nr 5-6, s. 11-12.

12. Por. szerzej A. Kabat, w: Prawo o postepowaniu przed sqdami administracyjnymi. Komentarz II, Warszawa 2005, s. 148. 
W świetle przywołanych stanowisk przedstawicieli doktryny oraz sądownictwa administracyjnego słuszny jest pogląd, że art. $54 \S 3$ p.p.s.a. stanowi dla organu administracji publicznej samodzielna podstawę do weryfikacji swojej decyzji. Argumentem, który za tym przemawia, jest skutek, jaki niesie ze sobą zaskarżenie decyzji administracyjnej do sądu, tj. wszczęcie postępowania przed sądem administracyjnym. Organ administracji publicznej, korzystając $\mathrm{z}$ wyjątkowego trybu przewidzianego w art. $54 \S 3$ p.p.s.a., działa więc niejako w ramach toczącego się postępowania sądowoadministracyjnego ${ }^{13}$.

Z powyższego wynika, że organ w trybie samokontroli dokonuje oceny aktu z punktu widzenia tych samych kryteriów, co sąd administracyjny. Autokontrola to specjalny tryb, w którym organ administracji publicznej rozpoznaje skargę niejako w zastępstwie sądu. Skoro tak, to organ administracji publicznej może wydać tylko takie rozstrzygnięcie, do jakiego upoważniony jest sąd administracyjny. Zgodnie z art. $147 \S 1 \mathrm{w}$ zw. z art. $3 \S 2$ pkt 5 p.p.s.a. sąd, uwzględniając skargę na akt prawa miejscowego, stwierdza jego nieważność.

Żądaniem skargi wojewody było stwierdzenie nieważności uchwały Rady Miasta z 27 kwietnia $2004 \mathrm{r}$. Wobec tego uwzględnienie w całości tej skargi przez organ administracji w trybie autokontroli mogło polegać wyłącznie na wydaniu takiego właśnie rozstrzygnięcia (wyrażonego w uchwale Rady Miasta z 16 grudnia 2013 r.).

\section{ROZSTRZYGNIĘCIA AUTOKONTROLNE}

Naczelny Sąd Administracyjny w uchwale z 5 lipca 1999 r. (FPS 20/98) stwierdził, że:

uprawnienia organu dokonującego autokontroli, określone w art. 38 ust. 2 ustawy o NSA, stanowią samodzielną podstawę postępowania prowadzonego przez organ administracji publicznej w ramach tej procedury, jak również samoistną podstawę do stosowania zróżnicowanych form rozstrzygnięć uwzględniających skargę.

Stanowisko to wyrażone zostało co prawda na gruncie poprzedniej ustawy, jednak pozostaje aktualne ze względu na fakt, że prawodawca podtrzymał instytucję samokontroli. Co więcej, posłużył się w art. 54 § 3 p.p.s.a. ogólną przesłanką „uwzględnienia skargi w całości”, rezygnując przy tym ze wskazania konkretnych dozwolonych form rozstrzygnięć organu administracyjnego ${ }^{14}$.

W piśmiennictwie powstał spór co do charakteru uprawnień autokontrolnych. Zasadnicze znaczenie ma kwestia samodzielności uprawnień autokontrolnych, a w szczególności tego, czy te uprawnienia stanowią część procesu sądowoadministracyjnego, czy też jest to szczególny przypadek postępowania administracyjnego wszczętego w sytuacji określonej w ustawie. Zdaniem części autorów uprawnienie autokontrolne stanowi nowe, samodzielne uprawnie-

${ }_{13}$ Por. K. Sagan, Instytucja samokontroli w trybie art. 54 par. 3 ustawy z 30 sierpnia 2002 r. Prawo o postepowaniu przed sqdami administracyjnymi w świetle pogladów doktryny $i$ orzecznictwa, „Przegląd Prawa Publicznego” 2014, nr 1, s. 40.

${ }^{14}$ Ibidem. 
nie organu administracji publicznej do weryfikacji własnej decyzji, wiążące się wyłącznie z zaskarżeniem tej decyzji do sądu administracyjnego. W orzecznictwie sądowym spór ten nie nabrał tak szerokiego rozdźwięku, albowiem dość powszechnie, również na płaszczyźnie obowiązującej ustawy, jest akceptowana uchwała składu siedmiu sędziów NSA z 5 lipca 1999 r. (FPS 20/98, Lex Polonica, nr 340233, ONSA 1999, nr 4, poz. 120), w której przyjęto, że uprawnienie organu dokonującego autokontroli (określone w art. 38 ust. 2 nieobowiąującej obecnie ustawy o NSA) stanowi samodzielna podstawę postępowania prowadzonego przez organ administracji publicznej w ramach tej procedury, jak również samoistna podstawę stosowania zróżnicowanych form rozstrzygnięć uwzględniających skargę. Podobnie wypowiedział się NSA w uchwale składu siedmiu sędziów z 20 marca 2000 r. (OPS 16/99, Lex Polonica, nr 345476, ONSA 2000, nr 3, poz. 94).

Za dopuszczalne należy uznać rozstrzygnięcie stwierdzające nieważność zaskarżonego aktu. W ramach uprawnień autokontrolnych organ może pozbawić mocy wiążącej i zastapić nowym rozstrzygnięciem jedynie te akty, które zostały wydane w danej sprawie administracyjnej. Konstrukcja przepisów wyznaczajacych zakres właściwości organu, do których odsyła art. 54 § 3 p.p.s.a., implikuje w tym wypadku węższe rozumienie sprawy niż to, z którym mamy do czynienia na płaszczyźnie art. 135 p.p.s.a. i które jest punktem odniesienia do określenia granic orzekania sądu. Artykuł $54 \S 3$ p.p.s.a. nie wymienia konkretnie form działania administracji, których zaskarżenie daje możliwość zastosowania instytucji autokontroli. Używa jedynie ogólnego sformułowania „działanie, bezczynność lub przewlekłe prowadzenie postępowania”. Należy przez to rozumieć, że przedmiotem autokontroli mogą być wszystkie formy działania lub bezczynności administracji publicznej objęte kognicją sądu administracyjnego (art. $3 \S 2$ i 3 p.p.s.a.) $)^{15}$.

\section{ZAKRES KOMPETENCJI RADY GMINY}

Wojewódzki Sąd Administracyjny w wyroku uznał, że uchwała Rady Miasta z 16 grudnia 2013 r. została podjęta z przekroczeniem kompetencji rady gminy, która - jego zdaniem - nie jest władna stwierdzić nieważności swojego aktu.

Jak słusznie wskazał Tarno, w przypadku takiego rozumienia należałoby stwierdzić, że w wyniku nowelizacji doszło do istotnego i całkowicie zbędnego ograniczenia uprawnień autokontrolnych organu administracji. Oznaczałoby to bowiem znaczne przedłużenie czasu załatwienia sprawy, i to w sytuacji, kiedy w opinii organu skarga jest całkowicie zasadna. Ponadto byłoby to równoznaczne z nieuzasadnionym zróżnicowaniem pozycji procesowej strony prze-

${ }^{15}$ B. Dauter, Metodyka pracy sędziego sqdu administracyjnego, wyd. 4, LexisNexis, Warszawa 2012 , s. 768 . 
ciwnej skarżącemu tylko ze względu na miejsce, jakie on zajmuje w systemie administracji publicznej ${ }^{16}$.

Treść art. 54 § 3 p.p.s.a. należy rozumieć zgodnie z wykładnią celowościowa i systemowa. Odnośnie do użytego ww. przepisie sformułowania „w zakresie właściwości” wypowiedział się Naczelny Sąd Administracyjny w postanowieniu z 29 grudnia 2009 r. (II OW 73/2009, Lex Polonica, nr 2320109): „A zatem, warunkiem skorzystania z uprawnienia do autokontroli, przewidzianym $\mathrm{w}$ art. $54 \S 3$ ppsa, jest posiadanie przez organ administracji publicznej - w dacie korzystania z tego uprawnienia - kompetencji do załatwiania danego rodzaju spraw administracyjnych".

Zgodnie z art. 18 ust. 2 pkt 5 u.s.g.: „Do wyłącznej właściwości rady gminy należy: [...] 5) uchwalanie studium uwarunkowań i kierunków zagospodarowania przestrzennego gminy oraz miejscowych planów zagospodarowania przestrzennego". Nie ulega wątpliwości, że Rada Miasta jest kompetentna do stanowienia $\mathrm{w}$ zakresie planowania i zagospodarowania przestrzennego gminy, a więc także do tworzenia miejscowego planu zagospodarowania przestrzennego. Ma zatem władzę do rozstrzygania w tego rodzaju sprawach.

Należy jednak przede wszystkim zwrócić uwagę na brzmienie art. 18 ust. 1 u.s.g., który stanowi: „Do właściwości rady gminy należą wszystkie sprawy pozostajace w zakresie działania gminy, o ile ustawy nie stanowia inaczej”. Ustawodawca wprowadził domniemanie kompetencji rady gminy. Zgodnie z ta generalną klauzula, jeśli z przepisów ustawy o samorządzie gminnym lub innych ustaw wyraźnie nie wynika, który z organów gminy jest właściwy do załatwienia określonej sprawy, to należy przyjąć właściwość rady. Określone w art. 18 ust. 2 sprawy należą - wolą ustawodawcy - do wyłącznej właściwości rady gminy, przy czym treść art. 18 ust. 2 pkt 15 in fine wskazuje, że nie stanowią one katalogu zamkniętego ${ }^{17}$.

$\mathrm{Z}$ kolei art. 15 ust. 1 u.s.g. określa charakter organu, jakim jest rada gminy, przyznając jej funkcje organu stanowiącego i kontrolnego w gminie.

Z uwagi na kompetencyjny charakter art. 18 u.s.g., do dokonania danej czynności, rada gminy winna opierać się na konkretnym przepisie prawa, który udziela jej takiego uprawnienia. W niniejszym przypadku jest to przepis art. $54 \S 3$ p.p.s.a.

\section{CEL AUTOKONTROLI}

Wprowadzenie przez ustawodawcę pośredniego trybu wnoszenia skargi podyktowane było wola przyspieszenia biegu postępowania w sprawie. Ponadto konstrukcja przyjęta w omawianym przepisie usprawnia ocenę dopuszczalno-

${ }_{16}$ Por. J. P. Tarno, Komentarz do dz. III roz. 2 art. 54, w: Prawo o postepowaniu przed sqdami administracyjnymi. Komentarz, wyd. 5, Warszawa 2012, s. 195.

${ }^{17}$ K. Wlaźlak, Komentarza do rozdz. 3 art. 18, w: K. Bandarzewski et al., Ustawa o samorzqdzie gminnym. Komentarz, Lex Polonica. 
ści skargi. Jednocześnie stwarza ona od razu (tzn. po dojściu skargi do organu administracji) możliwość uruchomienia trybu samokontroli przez ten organ.

Wykładnię celowościową przepisu art. $54 \S 3$ p.p.s.a. reprezentuje Naczelny Sąd Administracyjny w postanowieniu z 25 października 2011 r. (II GSK 2108/2011, Lex Polonica, nr 3068607):

\footnotetext{
Powszechnie przyjmuje się, że celem autokontroli jest umożliwienie organom administracji publicznej ponownej weryfikacji własnego działania (lub braku działania) bez konieczności angażowania sądu administracyjnego w ocenę jego zgodności z prawem. Autokontrola prowadzi w związku z tym do szybszego załatwienia sprawy, i to zgodnie z żądaniem skarżącego, a zatem służy realizacji zasady szybkości postępowania wyrażonej w art. 7 ppsa.
}

Jak podkreślił Naczelny Sąd Administracyjny w uchwale z 5 lipca 1999 r. (FPS 20/98) - podjętej na gruncie art. 38 ust. 2 ustawy z 11 maja 1995 r. o Naczelnym Sądzie Administracyjnym (Dz. U. 1995, Nr 74, poz. 368 ze zm.) - nie ulega wątpliwości, że unormowanie to ma umożliwiać organowi administracji publicznej weryfikację własnego działania bez potrzeby rozpatrywania sprawy przez sąd administracyjny. Rozwiązanie takie prowadzi do szybszego załatwienia sprawy, i to zgodnie z żądaniem skarżącego (pośrednie zrealizowanie jednej z zasad ogólnych Kodeksu postępowania administracyjnego - zasady szybkości i prostoty postępowania administracyjnego - art. $12 \S 1$ k.p.a.), nie angażuje też $\mathrm{w}$ rozstrzygnięcie sprawy sądu administracyjnego (por. ONSA 1999, nr 4, poz. 120).

Należy wskazać, że uwzględnienie skargi przez Radę Miasta w trybie autokontroli było zadośćuczynieniem zasadzie ekonomiki procesowej, doprowadziło bowiem do osiągnięcia celu jej wniesienia, co z kolei czyniło dalsze procedowanie w sprawie zbędnym. Doszło tym samym do wydania w sprawie nowego rozstrzygnięcia, które może być przedmiotem kontroli sądu (zgodnie z zasadą skargowości) tylko w razie zaskarżenia go przez stronę.

W konsekwencji przyjęcia przez wojewodę nieprawidłowej interpretacji przepisu art. $54 \S 3$ p.p.s.a. organ pominą ten przepis jako niemajacy zastosowania w rozpatrywanej sprawie. To zaś bez wątpienia miało istotny wpływ na jej wynik, spowodowało bowiem uznanie bezprawności wydanej w trybie „samokontroli” uchwały Rady Miasta.

\section{ART. 91 UST. 1 I ART. 93 UST. 1 U.S.G.}

Wojewódzki Sąd Administracyjny stwierdził, że organ będzie mógł uwzględnić zasadną skargę „wyłącznie wtedy, gdy przepisy określające jego właściwość na to zezwolą. Jednocześnie jako przeszkodę wskazał art. 91 ust. 1 oraz art. 93 ust. 1 u.s.g.

Tymczasem, jak stwierdził Paweł Chmielnicki, „Ustawa o samorządzie gminnym, co do zasady, nie wypowiada się na tematy proceduralne i ma zna- 
czenie jedynie uzupełniające (dokładniej - lex specialis) w stosunku do ustawy - Prawo o postępowaniu przed sądami administracyjnymi"18.

Przepisy rozdziału 10 ustawy o samorządzie gminnym pt. „Nadzór nad działalnościa gminy” określają organy sprawujące ten nadzór (Prezes Rady Ministrów, wojewoda, regionalna izba obrachunkowa), a także postępowanie nadzorcze w sprawie stwierdzenia nieważności uchwały lub zarządzenia w gminie. Normy te stanowia, że aż do upływu 30-dniowego terminu od dnia przedstawiania uchwały organowi nadzoru może on stwierdzić jej nieważność w własnym zakresie. Jednak po tym czasie kompetencja wojewody ogranicza się już tylko do uprawnienia do wniesienia skargi do sądu administracyjnego. $\mathrm{Na}$ tym rola organu nadzoru się kończy, ponieważ z momentem wniesienia skargi następuje zawisłość sprawy i zastosowanie znajdują regulacje ustawy p.p.s.a., w tym art. $54 \S 3$.

Należy rozróżnić takie etapy, jak postępowanie nadzorcze (wykonywane przez wojewodę poprzez wydanie rozstrzygnięcia nadzorczego bądź wniesienie skargi do wojewódzkiego sądu administracyjnego, o czym mowa w art. 91 i n. u.s.g.) od etapu postępowania sadowoadministracyjnego. To ostatnie wszczynane jest przez wniesienie skargi już z momentem wpływu do organu, za pośrednictwem którego skarga jest wnoszona. Wówczas przestają mieć zastosowanie przepisy o nadzorze wojewody nad działalnością gminy, w miejsce których wchodzą zasady postępowania sądowego określone w ustawie p.p.s.a. Przepisy art. 91 ust. 1 oraz art. 93 ust. 1 u.s.g. nie dotyczą już wszczętego postępowania przed sądem administracyjnym. Nie są zatem przepisami ograniczającymi art. $54 \S 3$ p.p.s.a.

Dlatego też z treści przepisów ustawy o samorządzie gminy nie można wywodzić ograniczenia kręgu podmiotów władnych do stwierdzenia nieważności uchwały w ogóle. Innymi słowy, uprawnienia do wyeliminowania z obrotu prawnego wadliwego aktu gminy nie można rozumieć wasko, tylko w granicach ustawy o samorządzie gminy, gdyż ona (w przepisach art. 91 i n.) reguluje tylko jedną z dróg - na wcześniejszym (przedsądowym) etapie. Oczywiste jest, że wówczas rada gminy nie ma prawa stwierdzić nieważności swojej uchwały, nie bowiem ku temu podstawy prawnej. Jednakże już po wniesieniu skargi do wojewódzkiego sądu administracyjnego organ gminy uzyskuje takie uprawnienie - na mocy z art. $54 \S 3$ p.p.s.a.

W omawianym zakresie przepisy ustawy o samorządzie gminy i Prawa o postępowaniu przed sądami administracyjnymi nie kolidują ze soba. Nie ma tutaj konfliktu wymagającego rozstrzygnięcia, która norma ma pierwszeństwo według obowiązujacych reguł kolizyjnych.

W związku z tym nie można zgodzić się ze stanowiskiem, że - zgodnie z art. 91 ust. 1 oraz art. 93 ust. 1 u.s.g. - organem właściwym do stwierdzenia nieważności uchwały rady gminy w ogóle jest wyłącznie wojewoda albo sąd administracyjny. Biorac pod uwagę odrębność postępowania nadzorczego wobec postępowania sądowoadministracyjnego, z ww. przepisów nie można wyprowadzić takiego wniosku.

\footnotetext{
${ }_{18}$ P. Chmielnicki, W. Kisiel, Komentarz do rozdz. 10 art. 100, w: K. Bandarzewski et al., op. cit.
} 


\section{WNIOSKI}

Reasumując, brak podstaw prawnych do odmówienia radzie gminy możliwości skorzystania z uprawnienia do „samokontroli” zaskarżonej przez organ nadzoru uchwały w sprawie miejscowego planu zagospodarowania przestrzennego. Skoro art. 54 par 3 p.p.s.a. stanowi samodzielna podstawę do wydania rozstrzygnięcia autokontrolnego, a przepisy ustaw nie wprowadzają ograniczeń rady gminy do stwierdzenia nieważności swojego aktu, należy stwierdzić, że jest to dopuszczalne. Przepisy art. 91 ust. 1 oraz art. 93 ust. 1 u.s.g. nie powinny być rozumiane jako ograniczające kompetencję rady gminy do stwierdzenia nieważności swojej uchwały w trybie autokontroli z art. 54 § 3 p.p.s.a.

prof. dr hab. Bogdan Dolnicki

Uniwersytet Ślaski w Katowicach

bogdan.dolnicki@us.edu.pl

\section{ANNULMENT OF AN ACT BY A COMMUNE AND MUNICIPALITY COUNCIL}

\section{Sum mary}

A resolution or a decree issued by a commune and municipality, district or voivoideship authority that is contrary to law is void. Annulment of such act of a local authority is recognised as a basic means of supervision. Accordingly, respective rules of conduct and procedure have been developed in relation to that means. Additionally, the law on commune and municipality and district self-government contains a reference to an appropriate application of the provisions of the Code of Administrative Procedure. This measure, however, has an adverse effect to that intended - instead of simplifying the proceedings in annulment; it has complicated them and led to many questions and conflicts emerging at the point where both acts overlap.

If a supervisory authority has not independently pronounced an act (decree) void within 30 days of delivery, its annulment may only be affected by an administrative court pursuant to a complaint filed by the supervisory authority. However, not all possible circumstances have been foreseen in the applicable law. 
